DOI: https://doi.org/10.34069/AI/2021.38.02.13

\title{
Human rights in the context of gender and juvenile policy in different legal systems
}

\section{Права людини в умовах гендерної та ювенальної політики в різних правових системах}

\author{
Written by: \\ Boris Perezhniak $^{36}$ \\ https://orcid.org/0000-0002-4096-0861 \\ Olga Melnychuk ${ }^{37}$ \\ https://orcid.org/0000-0002-3557-5934 \\ Mykola Matiiko $^{38}$ \\ https://orcid.org/0000-0003-4588-2636 \\ Hanna Kotyk ${ }^{39}$ \\ https://orcid.org/0000-0001-6494-2273 \\ Nargis Mokhd ${ }^{40}$ \\ https://orcid.org/0000-0002-9561-3074
}

\begin{abstract}
The study aims to identify the features of gender and juvenile policy in different legal systems and the formation of women's and children's rights. At present, equal rights are one of the main tasks of the modern social and legal state, as equality of rights and non-discrimination have been proclaimed by many constitutions and enshrined at the international level. The implementation of an effective gender and juvenile policy will increase the state's reputation in the international arena and ensure a high degree of trust in the government. Given the differences in the development of this aspect of countries from different legal systems, the analysis of the specifics of ensuring rights within gender and juvenile policy will further improve existing ways of regulating gender and juvenile relations by borrowing the main promising ideas and provisions underlying public policy. To conduct a research the authors used different scientific methods. Among these methods are the analysis and synthesis, the formal-legal and the comparative law method. The result of this work is to identify specific features characteristic of gender and juvenile policy of different legal
\end{abstract}

\begin{abstract}
Анотація
Дослідження направлене на виявлення особливостей гендерної та ювенальної політики в різних правових системах та становлення прав жінок та дітей. Наразі урівняння в правах є однією з основних завдань сучасної соціальної та правової держави, оскільки рівність прав та недопущення дискримінації проголошені багатьма конституціями та закріплені на міжнародному рівні. Здійснення ефективної гендерної та ювенальної політики дозволить підвищити рівень репутації держави на міжнародній арені та забезпечить високий ступінь довіри до влади. 3 огляду на відмінності у розвитку в даному аспекті держав 3 різних правових систем, аналіз особливостей забезпечення прав в межах гендерної та ювенальної політики дасть змогу подальшого удосконалення існуючих шляхів урегулювання гендерних та ювенальних правовідносин через запозичення основних перспективних ідей та положень, покладених в основу відповідної державної політики. Для проведення дослідження автори використовували різні наукові методи. Серед цих методів - аналіз та синтез, формально-
\end{abstract}

\footnotetext{
${ }^{36}$ Doctor of Legal Science, Professor of Constitutional Law Department of National University "Odesa Law Academy", Honored Lawyer of Ukraine, Academician of the National Academy of Sciences of Higher Education of Ukraine, Ukraine.

${ }^{37}$ Doctor of Legal Science, Professor of the Department of General Theoretical Jurisprudence of National University "Odesa Law Academy", Ukraine.

${ }^{38} \mathrm{Ph}$. D., Associate Professor of Civil Law Department of National University "Odesa Law Academy", Ukraine.

${ }^{39}$ Specialist of the Department of International Relations of South Ukrainian National Pedagogical University named after K.D. Ushinsky, Ukraine.

${ }^{40} \mathrm{Ph}$. D. candidate of the Department of International and European Law of National University "Odesa Law Academy", Ukraine.
} 
systems, determine the importance of human rights and non-discrimination, offer effective ways to improve the implementation of gender and juvenile policy on the example of progressive states.

Key Words: gender and juvenile policy, gender, principle of equality, principle of nondiscrimination, gender gap index.

\section{Introduction}

The presence of peculiarities of historical, social, and legal development of states has led to the formation of different legal systems that characterize the relationship of legal reality with the ideological, normative, institutional, and socio-economic vectors of politics of each state.

As Samilo successfully emphasizes, the legal system determines the entire system of legal phenomena in the state, the set of legal means by which regulatory influence on public relations is exercised. The legal system is usually understood as the legal organization of the whole society, in which law is the core (Samilo, 2015).

However, given that the subjective and objective factors that underlie the formation of the legal system in different countries have common features, the scientific legal literature adopted the position of classification of legal systems into types based on relevant criteria. Thus, the most common and optimal is the distribution of legal systems as follows:

1) Romano-Germanic type of legal system;

2) the Anglo-American type of legal system;

3) mixed, which includes a subtype of the Scandinavian and Latin American legal systems, and;

4) religious-traditional type of legal system, among which there are Muslim, Hindu, Jewish, Chinese, Japanese, and African groups (Topol, 2002).

Each of the above types of legal systems has its guidelines, but modernity makes significant adjustments to the basic ideas and organization of legal systems. As a result, legal phenomena and categories that are relevant and currently important for the development of society, to varying degrees are manifested in a particular правовий та порівняльно-правовий метод. Результат проведеної роботи полягає у виявленні специфічних рис, характерних для гендерної та ювенальної політики держав різних правових систем, визначення важливості дотримання прав людини та недопущення дискримінації, запропонуванні ефективних способів удосконалення здійснення гендерної та ювенальної політики на прикладі прогресивних держав.

Ключові слова: гендерна та ювенальна політика, гендер, принцип рівності, принцип недискримінації, індекс гендерного розриву.

legal system. In particular, the characteristics of gender and juvenile policy, which correspond to one or another type of legal system, also differ.

The object of the study is the relationship to human rights in the context of gender and juvenile policy in different legal systems. The subject of research - human rights in terms of gender and juvenile policy in different legal systems. The work intends to identify the features of the implementation of gender and juvenile policy in countries of different legal systems and their impact on the implementation of human rights.

\section{Theoretical Framework or Literature Review}

A large number of works by domestic and foreign scientists are devoted to the study of issues related to the research topic.

Thus, Moroz (2015) analyzes the principle of non-discrimination and compares it with the principle of equality, which makes it possible to understand the need to apply a comprehensive understanding of "equality". Pankevych's works reveal general theoretical and philosophical-legal aspects of interpretation of the prohibition of discrimination in the context of the case-law of the European Court of Human Rights, i.e. the meaning and consequences of discrimination in court precedents, which are mandatory.

Also, Hristova (2013) emphasized the duty of the state to promote equality and avoid discrimination. What is more, Ivchenko's (2009) works were aimed at studying the concepts of "gender", as well as their role in state policy; the essence of the state's gender policy is revealed. Besides, Bobrova (2019) studied foreign experience in ensuring women's rights within the 
framework of gender policies pursued by various countries and concluded that there were generally positive international experiences and high standards of implementation of the principle of gender equality.

Finally, Golyak's (2011) work is also devoted to the international experience of implementing the principle of gender equality, in particular, within the framework of the effectiveness of the relevant bodies or specialized persons who are empowered to monitor and control the provision of equal opportunities for persons of different sexes.

However, some issues need further study, in particular on the predominant role of the principle of non-discrimination over the principle of equality in the implementation of gender and juvenile policies; comparison of the effectiveness of ensuring the rights of women and children in demonstrative foreign countries of different legal systems; definition of an effective formula for effective protection of human rights, etc.

\section{Methodology}

Firstly, the analysis and the synthesis methods made it possible to provide a general description and characterization of a certain gender and juvenile policies of the Romano-Germanic, Anglo-Saxon, mixed, and religious legal systems, to identify and compare basic positions on the legal regulation of women's and children's rights.

Analysis is a decomposition, division of something integral into constituent elements, properties, relations, aspects, subsystems for further in-depth consideration of each of them. Not being able to decompose speculative structures into constituent parts in the literal sense, the method of abstraction was used within the specified method. This allowed to thoroughly analyze and compare legal systems in terms of their attitude to the concept of human rights. On the other hand, synthesis is a combination of disparate knowledge about an object, its parts and properties, and its reflection as a certain whole, an interconnected system, the process of formation (assembly, construction) of a whole object. It is this method that has made it possible to combine the individual manifestations of the attitude of different legal systems to the problem of ensuring the equality of women's and men's rights, as well as ensuring the rights of minors, into a single concept. In particular the methods of analysis and synthesis in their interrelation allowed to draw a conclusion that the successful policy-making mechanism to ensure equal gender rights can be presented as the "rule of three R's": representation, resources, reality.

As for the formal-legal (dogmatic, legaltechnical) method - it is traditionally used to study the "dogma" of law, its internal and external form. Analysis of the sources of law, the formal definition of law, the order of systematization of normative material, the rules of legal technique are manifestation of this method. As for this research the formal-legal method helped to clarify the essence and content of such legal categories as equality, discrimination, gender, and juvenile policy according to the legislation of different countries and legal systems. Besides it helped to identify the discriminatory provisions in Middle Eastern law.

Thanks to the comparative law method, it became possible to compare the main legal positions of different states of the RomanoGermanic, Anglo-Saxon, mixed, and religious legal systems, including Germany, Spain, Sweden, as well as taking into account the specifics of each gender and juvenile policy. In particular, it is established that in European countries, regardless of the type of legal system, serious attention is paid to ensuring gender rights and children's rights. In a number of countries, the institution of an ombudsman for children's rights has been introduced, and in Sweden there is also the institution of the ombudsman for equal rights of men and women.

\section{Results and Discussion}

Gender and juvenile policy of all legal systems is based on the universally recognized legal principle of equality of human rights, which borders on the principle of non-discrimination.

Currently, there is no single approach to the final recognition of the independence of the principle of non-discrimination, in connection with which the legal science is actively developing discussions about the relationship of the above principles of law.

Thus, the prohibition of discrimination in Art. 14 of the European Convention for the Protection of Human Rights is, in essence, the implementation of the principle of equality enshrined in other provisions of the Convention. A similar view is held by Pankevych (2014), who argues that the requirement of non-discrimination (prohibition of discrimination) is one of the components of the common law principle of equality. 
According to Hristova (2013), the principle of non-discrimination exists as a sub-principle within the principle of equality, namely within the concept of real equality or so-called "equality through law". Equality, in this case, is ensured by introducing positive actions by the state to resolve de facto inequality.

Kretova-Alyoshina (2012), on the contrary, explains the difference between these principles by the fact that these principles, although related, but have different meanings, differ in essence (the principle of equality is based on creating equal conditions for a person to exercise their rights, and the principle of non-discrimination to create conditions for inadmissibility of restrictions on human rights, freedoms and responsibilities depending on anthropological or social characteristics). Moreover, she calls the principle of non-discrimination constitutional, inalienable, and a continuation of other constitutional principles - justice, equality, respect for human rights.

According to the author, the principle of nondiscrimination should be considered an independent principle, even though it is derived from the principle of equality.

The principle of non-discrimination means the absence of any restrictions or encumbrances on human rights and freedoms based on the existence of a factor. The principle of equality embodies a more global conception - the idea of equal rights and freedoms for everyone.

One of the main points in the interpretation of the relationship between the principle of equality and the principle of non-discrimination belongs to the European Court of Human Rights. In its judgments, the Court has repeatedly interpreted the concept of "discrimination". He views discrimination as any different treatment of persons who are in the same situation, where such treatment is based on a particular human trait and has no objective reasonable justification (European Court of Human Rights, 2011). The principle of non-discrimination can be equated with the principle of equal treatment (European Court of Human Rights, 2007), but not with the principle of equality in general. The principle of non-discrimination guarantees respect for human and civil rights and is considered by the European Court as "equal protection by law without any discrimination".
Against the background of the above provisions, there is a "principle of gender equality", "principle of equality between women and men", etc., which is a continuation of the content of the principle of equality in symbiosis with the principle of non-discrimination.

The principle of gender equality stipulates that economic, political, and social resources should be distributed equally between men and women in general, without significant disparities, unequal conditions in access to social resources (Ivchenko, 2009). According to the principle of gender equality, economic, political, and social resources must be shared equally between men and women (Nechaeva, 2007).

The principle of gender equality is intended to implement primarily the methodological function - to provide tools and methods for effective implementation of human rights. The principle of gender equality serves as a goal that must be taken into account in lawmaking and law enforcement (Chvykalov, 2012).

The main idea of the current principle is to change the established vision of the rights of men and women, their social and status roles, legal values. Full implementation of gender equality should ensure the possibility of women being on an equal footing with men in all spheres of public life: politics, economics, science, spirituality, etc.

At the same time, in shaping gender policy, the state, regardless of the type of legal system it is more inclined to, must take into account the historical age-old traditions regarding the role of women and men in society. For this reason, "equality" should include the right to distinction, which necessitates the consideration of the distinctive features of men and women, which are related to their belonging to a particular class, their political views, religion, ethnic group, etc. (Venger, 2009).

According to the author, the above statement complicates the practical implementation of the principle of equality, because to achieve equality in the presence of a deliberately biased attitude, i.e. separation, the gender of women against the gender of men.

That is why the author is convinced that the principle of non-discrimination, which should play a leading role concerning the principle of equality, should be the basis of an effective gender policy. 
Thus, discrimination is a socially dangerous illegal act (action or omission), expressed in the form of distinction, exclusion, restriction, exclusion, or advantage caused by various determinants, aimed at discrediting the state before its citizens, non-compliance with human rights and freedoms, violation of international obligations, constitution, sectoral legislation, which entails the moral and physical suffering of the victim, committed by an official or group of persons (Larinbaeva, 2004).

Thus, gender policy should be aimed at preventing discrimination against men and women.

A similar situation has developed within the implementation of juvenile policy, which aims not only to protect the rights of children but also to create the closest possible conditions for the realization of their rights and freedoms to the opportunities of adults, taking into account the extent of the child's capacity and its social role to address some social issues.

Gender and juvenile policies have different levels of development in states, depending on the recognition of their importance, public perception, and implementation methods.

However, at the international level, the importance of gender equality is confirmed, in particular, by the annual study of the Global Economic Forum (The Global Gender Gap Index), which is measured by four indicators:

1) economic participation;

2) political activity of genders;

3) level of education, and;

4) ensuring access to health care and life expectancy.

As of 2019, according to the above study, the most positive states of gender equality are demonstrated by Western Europe (76.7\%), North America (72.9\%), Latin America and the Caribbean (72.2\%), Eastern Europe and Central Asia (71.3\%), sub-Saharan Africa (68.2\%), South Asia (66.1\%), the Middle East, and North Africa (60.5\%) (Zhachesk, 2019).

Thus, the country with the highest degree of gender equality in Iceland (11th year in a row) (gender gap is closed by $88 \%$ ). Among other countries in the world with indicative results on the gender gap index: Norway (84.2\%), Finland $(83.2 \%)$, Sweden (82\%), Nicaragua (80\%), New Zealand (79.9\%), Ireland (79.8), Rwanda (79.1\%), Germany (78.7\%), Spain (79.5\%),
Albania (76.9\%), Mexico (75.4\%), Austria (74.4\%), and Ethiopia (70.5\%) (Zhachesk, 2019).

Each of these states belongs to different legal systems, but groups of countries of a separate legal system are characterized by common features of gender policy.

Thus, the states of the Romano-Germanic (continental) legal system are characterized by the presence of legislative enshrinement of gender policy in regulations, usually headed by single target legislation (Japan, France, Germany, Croatia, Romania, and Ukraine). Simultaneously, the range of models of influencing gender relations varies from genderneutral with formal equality to paternalistic, which is characterized by a set of so-called positive actions (Leskina, 2012).

According to the gender gap index, Germany, which belongs to the Romano-Germanic legal family, is one of the ten countries with the best indicators of equality between women and men. This provision is largely an achievement of the gender policy (Gltichstellungspolitik) pursued in the state since 1970, the beginning of which should be considered the adoption of laws on women's equality (Frauenfordergesetze), which through quotas guarantee increased representation of women in leadership positions.

In 2016, the German regulatory framework in the field of gender equality reached a new, more specific level, which was marked by the adoption of law according to which public quotas with more than 2,000 employees are assigned a quota (women must hold on the board of directors or other responsible body at least $30 \%$ of the total number of managers).

Thus, the gender gap index was reduced due to the participation of women in the economic sphere, which ensured the latter the full realization of the right to work, the right to decent pay.

A feature of Germany's gender policy is the inclusion of a "male" factor in it. Thus, maternity leave for men is no exception in Germany. However, it should be noted that there is currently a prejudice against such men by management and colleagues, which indicates that society plays an important role in equalizing the rights of men and women, i.e. its attitude to such equality. 
Besides, Germany has introduced "childcare pension benefits" since 2014, the idea of which is to include both men and women on maternity leave in the event of a child being born before 1992.

And although Germany is a progressive state within the framework of gender equality, some bureaucracies in the understanding of gender still remain and, as an example, are manifested even in the name of innovations, in particular, the above-mentioned "maternal pension" (Mütterrente).

The high level of women's rights in Germany is ensured, among other things, by the system of public administration. For example, the procedure for the training, selection, and appointment of judges in Germany is regulated by Section 2 "Right to hold judicial office" of the German Law on Judges. The Equal Opportunities for Women Applicants (Gender Balance Optimization Rules) require that a person be involved in certain stages of the procedure, who must monitor and control the application of these rules (Gleichstellungsbeauftragte, such departments exist in all administrations).

Another striking example of the formation of gender equality based on the adoption and implementation of legislation is Spain. However, according to the author, Spain's gender policy is not based on the principle of non-discrimination but is achieved by giving women preferences to protect them and equalize their rights with men. For example, in 2004, Spain passed the Law on Comprehensive Measures to Protect Against Gender-Based Violence, which defined a unique mechanism for protecting women who have suffered from gender-based violence, and in 2015 a specialized gender court was established (Bobrova, 2019).

Characteristic of the Anglo-American (AngloSaxon) type of legal systems (UK, United States, Canada) is a liberal model that minimizes state participation in addressing issues of gender equality. However, equality indicators should not be considered low, as the formal lack of regulation and ensuring gender equality in practice does not prevent the state from creating appropriate conditions for giving women and men equal opportunities (to exercise their rights and freedoms in various spheres of public life).

For example, Canada is actively promoting the idea of equal rights for men and women by reforming vocational training, which introduces special courses to prepare women and men for professions that are stereotypically considered "female" or "male." This program is aimed, in particular, at creating decent conditions to encourage women in professions related to cars, maintenance, etc., and men - professions in the provision of social services or assisted medical practice. For such training, special gendersensitive methods and materials have been developed, which provide a comfortable learning environment and promote opportunities for the professional realization of women and men following the needs of the labor market (USAID, 2015).

The features of the Romano-Germanic and Anglo-Saxon legal families are rightly combined in mixed-type states, which include, in particular, Sweden.

Gender issues in Sweden are addressed by a symbiosis of methods based on representation, resources, and reality. Representation is the introduction of statistics (counting the number of staff, management, customers, suppliers, users, and all interested to determine the total number of men and women in all categories, i.e. how many men and how many women are in management, how many works with customers, etc.), based on which the basis of gender policy is developed. Besides, it is necessary to find out how resources (financial, time, information, human) are distributed between men and women. Finally, one should know why the representation and distribution of resources are unequal among women and men. Such comprehensive analysis of the problem allows to solve it systematically (Onishchenko, 2012).

The result of such public administration is the establishment of one of the highest rates of women working at the level of men. The rate of girls/women students and men on childcare leave is similar.

Sweden's gender policy is supported, in particular, by the existence of state supervision. Thus, in this state, the institution of the ombudsman for equal rights of men and women functions effectively. In addition, the Swedish government has introduced a special position of Deputy Prime Minister for Gender Equality, the main task of which is to expertly assess gender equality in all decisions of the Cabinet of Ministers and monitor the activities of all ministers to respect and ensure equality between men and women (Golyak, 2011). 
According to the author, the application of the "rule of three R" can be an effective formula for the effective protection of human rights in the context of gender and juvenile policy for most states, and therefore each state should be equal to the above legal experience.

Concerning ensuring the rights of children, the states of the above-mentioned legal systems at the constitutional level pay considerable attention to the equality of children's rights, as well as to the functioning of legal and social institutions designed to ensure such equality. Such a policy is based on the creation of an extensive social security system, guaranteeing judicial protection of rights and freedoms (in some countries due to the existence of juvenile justice), the functioning of the institution of children's ombudsman (Norway, Poland, Russia) or the performance of these functions by national ombudsmen, the existence of developed civil society institutions that monitor the observance of children's rights.

The constitutional norms of modern states guarantee appropriate protection and working conditions for minors, a decent wage but set age restrictions on the exercise of this right (Article 37 of the Constitution of the Italian Republic of 1947, Article 16 of the Constitution of the Republic of Malta of 1964, Article 42 of the Constitution of the Republic of Macedonia of 17 November 1991, Article 45 of the Constitution of the Republic of Lithuania of 25 October 1992, Article 65 of the Constitution of the Republic of Poland of 2 April 1997) (Schultz, 2009).

Currently, a positive and popular trend among developed countries is the introduction of a separate system of juvenile justice, which is designed to ensure the proper realization of their rights and interests by minors.

At the same moment, it is too early to talk about the high average rate of equality of children's rights within the framework of juvenile policy.

Thus, it can be stated that the material and legal framework for the rights of the child is properly provided and meets international requirements and standards, but the organizational "block" of juvenile law needs to be improved, as an effective mechanism for equal rights of children is not yet established.

Religious (traditional) legal systems can currently be considered the most vulnerable and unfavorable for the implementation of the current high-level gender and juvenile policy, as in such systems the patriarchal worldview still prevails. In particular, in such countries, purely male and purely female rights are enshrined in law, and women, respectively, have a significantly smaller number of rights than men.

Such countries currently include the Islamic Republic of Afghanistan, the United Arab Emirates, the Republic of Yemen, the Syrian Arab Republic, the Republic of Iran, the Republic of Iraq, Saudi Arabia, etc.

At the same instant, progress in this area can still be observed. Hence, the greatest hope for Arab women in the fight for their rights are modernists or Islamic feminists. Islamic feminists are convinced that the "patriarchal interpretation" of the Holy Scriptures of Muslims has led to significant discriminatory provisions in Middle Eastern law: the right of men to marry a nonMuslim woman, the virtually unilateral right of men to divorce, the parent's preemptive right to a father, etc.

In interpreting the problems of women and gender inequality from the point of view of Islam, Islamic feminists are guided by the idea of a new interpretation of the Qur'an and hadiths, recognizing the principle of equality between men and women (Igoshyna, 2010).

Currently, the states of the religious legal system are actively involved in the implementation of the ideas of gender equality. Thus, according to the annual report "UN Women" for 2019-2020, the United Arab Emirates is among the 15 sponsors of the organization. Afghanistan, Algeria, Bangladesh, Iraq, Libya, and Morocco also made voluntary contributions to UNWomen in 2019 (United Nations, 2020).

This declares the intention of these Islamic states to combat discrimination on the grounds of sex and to protect the rights of women. Such financial contributions ensure the implementation of UN Women projects and strengthen the global impact on human rights.

For example, during the COVID-19 pandemic, UN Women (2020) helped direct money grants to women and create national standards for the protection of women and children in quarantine facilities in Indonesia, and the national Salam for Safety campaign in Afghanistan used images of strong Afghan women to promote social distancing by traditional greetings without touching the year. 
However, discrimination and human rights abuses in religious legal states still exist in unsatisfactory numbers. The issue of gender equality between women and children is particularly acute in countries where there are military conflicts. One such country is currently Syria.

Resolution 43/28 on the human rights situation in the Syrian Arab Republic expresses its deep concern that sexual and gender-based violence against women, girls, men, and boys has been a constant problem in the Syrian Arab Republic since the 2011 uprising. The international community actively condemns all acts of sexual and gender-based violence and ill-treatment; recognizes the need to prevent and respond to such violence and ill-treatment; calls for immediate and non-discriminatory access to services such as medical and psychosocial support (to be provided to all survivors of such crimes); to make every effort to ensure justice for those affected by such crimes, and; calls on all parties to the conflict to respect and protect the full rights of women and girls (United Nations, 2020).

Resolution 43/28 also expressed deep concern about the civilian population, including children killed or maimed by landmines, explosive remnants of war, and improvised explosive devices used by all parties to the conflict (United Nations, 2020). Regrettably, children continue to be subjected to serious violations and abuses, including murder, abduction, use or recruitment by armed persons, mutilation, injury, and orphanhood, bearing the brunt of violence perpetrated by hostile parties. The use of schools for military purposes is strongly condemned. Resolution 43/28 calls on all parties to respect and protect the full enjoyment by children of all their rights, to ensure access to basic services such as medical care and education, and to provide official documents such as birth and education certificates, and to provide humanitarian workers with unhindered access to children and families in need of life-saving assistance; to prevent and protect children from all forms of exploitation, abuse and abuse, including sexual and gender-based violence and child, early and forced marriages, abuse, and torture, inter alia, by stopping and preventing the recruitment and use of children in armed conflict (immediately, safely and unconditionally releasing children) (United Nations, 2020).

\section{Conclusions}

Equality issues are addressed differently in different legal families, but the need for effective gender and juvenile policies is recognized by all States and supported at the international level.

Gender inequality is associated with historical traditional notions of the role of each particular gender, which excludes the equal position of women and men in politics, science, economics, etc.

The implementation of gender and juvenile policy is mainly based on the adoption of relevant legal acts, which, in the author's opinion, should be based on the principle of nondiscrimination and implemented, in particular, through the introduction of control institutions (e.g. ombudsman for gender equality).

A successful policy-making mechanism to ensure equal gender rights can be considered the "rule of three R's": representation, resources, reality.

At present, the issues of ensuring equal rights are acute for countries with a religious legal family, as they need not only changes in state regulation but also the legal consciousness of the local society.

\section{Bibliographic references}

Bobrova, Yu. Yu. (2019). Review of the international experience of realization of gender parity: separate questions. Legal novel, 8, 7-15. Recovered from http://www.legalnovels.in.ua/journal/8_2019/8_ 2019.pdf\#page $=7$

Chvykalov, V.V. (2012). Gender equality in law: historical and legal research (doctoral thesis). North Caucasian Scientific Center of Higher School of the Southern Federal University, Rostov-on-Don. Recovered from https://www.dissercat.com/content/gendernoeravenstvo-v-prave-istoriko-pravovoe-

issledovanie/read

European Court of Human Rights. (2007). D.H. and Others v. the Czech Republic, (application no. 57325/00). Recovered from http://hudoc.echr.coe.int/app/conversion/pdf/?li brary=ECHR\&id=003-2176193-

2313650\&filename $=003-2176193-2313650$.pdf European Court of Human Rights. (2011). Stummer v. Austria, (application no. 37452/02) Recovered 
http://hudoc.echr.coe.int/webservices/content/pd f/001-105575?TID=ihgdqbxnfi

Golyak, L.V. (2011). Specialized ombudsmen in gender mainstreaming: the experience of the Scandinavian countries. State and law: a collection of scientific papers, 52, 179-183. Recovered from http://lucl.kiev.ua/imageos/stories/zakachky/doc 995.docx

Hristova, G. (2013). Positive responsibilities of the state in the field of anti-discrimination. Bulletin of the National Academy of Legal Sciences of Ukraine 2013, 4(75), 11-20. Recovered from http://www.irbisnbuv.gov.ua/cgi-

bin/irbis_nbuv/cgiirbis_64.exe?C21COM=2\&I2 $1 \mathrm{DBN}=\mathrm{UJRN} \& \mathrm{P} 21 \mathrm{DBN}=\mathrm{UJRN} \& Z 21 \mathrm{ID}=\& \mathrm{IM}$

AGE_FILE_DOWNLOAD=1\&Image_file_nam e=PDF/vapny_2013_4_4.pdf

Igoshyna, Zh. (2010). Gender issues and processes of globalization in the Arab East. Scientific Bulletin "Actual Problems of International Relations" of the Institute of International Relations of Kyiv National University. T. Shevchenko, 94(2), 74-83. Recovered from http://law.journalsofznu.zp.ua/archive/visnik-42012-1/4(1)-2012.pdf\#page $=182$.

Italian Republic. (1947). Constitution. Recovered from https://www.wipo.int/edocs/lexdocs/laws/en/it/it 037en.pdf.

Ivchenko, Yu. V. (2009). Philosophical and legal analysis of gender policy in Ukraine (doctoral thesis). Kyiv National University of Internal Affairs of Ukraine, Kyiv. Recovered from http://www.disslib.org/filosofsko-pravovyianaliz-hendernoyi-polityky-v-ukrayini.html.

Kretova-Alyoshina, I. A. (2012). Constitutional principle of non-discrimination in the Russian Federation (doctoral thesis). Saratov National Research State University named after N.G. Chernyshevsky, Saratov. Recovered from http://www.dslib.net/konstitucionpravo/kretova-aljoshina-konstitucionnyjprincip-nediskriminacii-v-rossijskoj-

federacii.html

Larinbaeva, I. I. (2004). Legal ontology of gender equality (doctoral thesis). Bashkir State University, Ufa.

Leskina, I.E. (2012). Issues of gender equality in legal doctrine: genesis and current research priorities. Bulletin of Zaporizhia National University, 4(1), 182-191. Recovered from http://law.journalsofznu.zp.ua/archive/visnik-42012-1/4(1)-2012.pdf\#page=182.

Moroz, Y.K. (2015). The principle of nondiscrimination: the concept and relationship with the principle of equality. Proceedings: Legal sciences, 1, 39-42. Recovered from http://ekmair.ukma.edu.ua/bitstream/handle/123 456789/7857/Moroz_Pryntsyp_nedyskryminatsi i.pdf.

Nechaeva, O.V. (2007). Gender problems of Russia as a social state (doctoral thesis). Mordovian State University named after N.P. Ogareva, Saransk. Recovered from https://www.dissercat.com/content/gendernyeproblemy-rossii-kak-sotsialnogo-gosudarstvakonstitutsionno-pravovoe-issledovanie Onishchenko, I.G. (2012). Gender policy of the European Union: the agenda for Ukraine. Bulletin of Mariupol State University. Series: philosophy, culturology, sociology, 4, 12-15. Recovered from http://nbuv.gov.ua/UJRN/Vmdu_fks_2012_4_4 Pankevych, O. (2014). Prohibition of discrimination: some general theoretical and philosophical and legal aspects of interpretation (based on the case law of the European Court of Human Rights). Bulletin of the National Academy of Legal Sciences of Ukraine, 3(78), 20-31. Recovered from http://nbuv.gov.ua/UJRN/vapny_2014_3_4 Republic of Lithuania. (1992). Constitution. Recovered from https://www.wipo.int/edocs/lexdocs/laws/en/lt/lt 045en.pdf

Republic of Macedonia. (1991). Constitution. Recovered from https://www.ilo.org/dyn/natlex/docs/ELECTRO NIC/36714/70972/F511737559/MKD36714\%2 0Eng.pdf

Republic of Malta. (1964). Constitution. Recovered from https://www.wipo.int/edocs/lexdocs/laws/en/mt/ mt010en.pdf.

Republic of Poland. (1997). Constitution. Recovered from https://www.sejm.gov.pl/prawo/konst/angielski/ kon1.htm

Samilo, G.O. (2015). Mixed legal systems: problems of classification. Scientific Bulletin of Uzhhorod National University: Law, 33(1), 46-49.

Schultz, O.A. (2009). Genesis of modern doctrine of children's rights in foreign countries: constitutional and legal aspects. UkrainianGreek International Scientific Legal Journal "Comparative Legal Research", 2, 91-96. Recovered from http://dspace.nbuv.gov.ua/bitstream/handle/123 456789/18386/17-Shults.pdf.

Topol, Y.O. (2002). Legal systems of modernity: concepts and problems of modernity. Bulletin of the Khmelnytsky Institute of Regional Management and Law, 4, 27-34. Recovered 
from

http://nbuv.gov.ua/UJRN/Unzap_2002_4_6.

UN Women. (2020). The world for women and girls: annual report 2019-2020. Recovered from http://surl.li/knoy.

United Nations. (2020). Report of the Human Rights Council. Recovered from https://undocs.org/A/75/53.

USAID. (2015). Top 10 gender policies. Recovered from https://radaprogram.org/sites/default/files/public ations/top-10_web.pdf.

Venger, O.M. (2009). Formation and features of functioning of gender democracy in the modern
Ukrainian society. Kyiv: Pravo. Recovered from http://irbis-nbuv.gov.ua/cgi-

bin/irbis_nbuv/cgiirbis_64.exe?C21COM=2\&I2

$1 \mathrm{DBN}=\mathrm{ARD} \& \mathrm{P} 21 \mathrm{DBN}=\mathrm{ARD} \& \mathrm{Z} 21 \mathrm{ID}=\& \mathrm{Imag}$ e_file_name $=$ DOC/2009/09vomsus.zip $\& I M A G$ E_FILE_DOWNLOAD $=1$

Zhachesk, N. (December 20, 2019). Gender Gap Index 2020: it will take 100 years to bridge the global gender gap. 50Vidsotkiv. Recovered from https://50vidsotkiv.org.ua/gender-gap-index2020-politichna-uchast-zhinok-korelyuyetsyazi-zrostannyam-kilkosti-zhinok-kerivnikiv/ 